\title{
POETYCKIE SYMFONIE KAROLA WOJTYŁY
}

\author{
1.
}

W znanym liście do Mieczysława Kotlarczyka z listopada 1939 roku, tłumaczącym okoliczności powstania oraz intentio auctoris Psatterza Dawidowego (Księgi Słowiańskiej), pisał Karol Wojtyła:

Otóż chciałem stworzyć wyłom niejako. Wbrew kolegom moim, którzy się grążą ciągle jeszcze w rozpamiętywaniu wspaniałości Tuwima, cudnej - sam to przyznaję - melodii Lieberta, endeckiej bojowości Gałczyńskiego, czy wreszcie panteistycznej liryki Leśmiana. Pieśni Słowianina. Sonety. My pokolenie najmłodsze mamy wiarę Polonów, co sodalisem Maryjnym był, a szkaplerzem jak puklerzem krył piersi swoje. Polskość łacińska w oparciu o chrystianizm jest siłą ogromną, królestwem ducha, ideą ukochania godną najwyższego. Bo dla nas duch jest więcej niż przemoc i miecz; bo w nas są korzenie Piękna przegłęboko, bo Piękno nasze i sztuka nasza z naszego jest Narodu i dla naszego Narodu: to pieśń Wieszczów, Teatr Wyspiańskiego, Księgi Kasprowicza i filozofia Norwida. W nich jest linia wielkiej poezji polskiej, pieśń nie przebrzmiała, która naród jak w owym Genezis z Ducha mocą wypracy i ofiary ku górze prowadziła i ku wyzwoleniu ... . Trza się odrodzić i odróżnić. I próbą młodzieńczą tego są owe liryki: sonety i sy m fo ni e, i hymny. (Dzieta literackie 351; podkr. - AS)

O ile jednak sonety i hymny (a właściwie hymn Magnificat jako jedyny reprezentant tego gatunku w tomie) doczekały się pogłębionej uwagi badawczej, także w kontekście wersologicznym i genologicznym (zob. m.in. Dziedzic, „Pieśń polskim i słowiańskim duchem przepojona”, Chrząstowska, „«Pieśni - przeczucia»”, Przybylska, „O Renesansowym psałterzu Karola Wojtyły”), to „symfonie” przywołane

Dr hab. Agata Seweryn prof. KUL; Katedra Literatury Polskiej Oświecenia i Romantyzmu, Instytut Literaturoznawstwa KUL; adres do korespondencji: Katolicki Uniwersytet Lubelski Jana Pawła II, Al. Racławickie 14, 20-950 Lublin; e-mail: aseweryn@kul.pl. ORCID: http://orcid.org/ 0000-0003-3818-8195. 
przez autora w charakterze paratekstu, z wyraźną intencją formalną - Symphonie - Scalenia to przecież tytuł jednego z cykli wchodzących w skład Psałterza Dawidowego - pozostają dla komentatorów w znacznym stopniu przezroczyste. Sporo

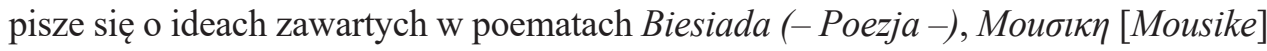
i Slowo - hogos [Logos] tworzących owe Symphonie..., jednak fakt, że poeta nazwał je „symfoniami” właśnie, jest pomijany. Zatem istota „symfonii” i „symfoniczności” w ujęciu młodego Karola Wojtyły - interesująca także w perspektywie komparatystyki intersemiotycznej, literacko-muzycznych dialogów i powinowactw, czy inaczej jeszcze mówiąc: „muzyczności” literatury - będzie przedmiotem niniejszego szkicu.

Psalterz Dawidów, nazywany przez autora także Księga Stowiańską i Renesansowym psałterzem, ma, jak wiadomo, status dość szczególny. Wiersze napisane przez nastoletniego poetę - studenta pierwszego roku filologii polskiej (niektóre być może jeszcze przez ucznia szkoły średniej - zob. Burghardt 221-236), pominięte zostały w pierwszej, przygotowanej dla Wydawnictwa Znak, edycji jego Poezji i dramatów. Zapomniał o nich nawet sam Jan Paweł II, który nie tylko nie był „tak bardzo zachwycony swoją młodzieńczą twórczością" (cyt. za: Popiel 20), ale też przez jakiś czas nie dowierzał, że niektóre spośród tych utworów - jak Magnificat - rzeczywiście on napisał ${ }^{1}$. Bardzo znamienne - i dowodzące samoświadomości młodego poety jest zdanie z cytowanego tu już listu dołączonego do rękopiśmiennych fragmentów Księgi Stowiańskiej przesłanych Kotlarczykowi: „Widzisz, ja się w tych wierszach po prostu uczę mówić, zanim zacznę rozmawiać" (Dzieła literackie 351-352). Wydaje się, że można je odczytywać nie tylko w kontekście przygotowań Wojtyły - „człowieka teatru” - do pisania dramatów (Popiel 9), czy tylko jako „laboratorium serca i myśli” przyszłego kapłana, kardynała i papieża (Dziedzic, „Pieśń nieprzebrzmiała” 416), ale także w związku z nabywaniem przez adepta sztuki poetyckiej umiejętności samodzielnego i swobodnego posługiwania się zasobami konwencji zachowanych w literackiej rekwizytorni epok minionych, w przypadku tej twórczości: tradycji polskiego renesansu i - zwłaszcza - romantyzmu i neoromantyzmu². „Poetycką symfonikę” Wojtyły skłonna więc jestem traktować jako $-\mathrm{z}$ jednej strony - nieco jeszcze scholarskie nawiązanie do idei romantycznej

${ }^{1}$ „Zupełnie o nich zapomniałem [...]. Co do Magnificat miałem zawsze wątpliwości, ale teraz nabrałem przekonania, skoro utwór ten znalazł się w rękopisie u Państwa Kotlarczyków" - miał powiedzieć Ojciec Święty do ks. Stanisława Dziwisza (list z 14 lutego 1994, prywatne archiwum Stanisława Dziedzica; cyt. za: Popiel 20).

${ }^{2}$ Związki twórczości Wojtyły z tradycją literacką to temat częsty w literaturze przedmiotu. Dotknął tych kwestii już Wiesław Paweł Szymański (Z mroku korzeni), potem do tych wątków powracano wielokrotnie, zob. m.in.: J. Maciejewski, Dybciak, Karol Wojtyła a literatura, Przybylska, „Źródła mistyki «Poezji i dramatów»", Urbanowski, Kozłowska, Seul, Karol Wojtyła/Jan Paweł II, red. Halkiewicz-Sojak i in. 
correspondance des arts oraz jej młodopolskich i tworzących w dwudziestoleciu międzywojennym kontynuatorów ${ }^{3}$. $Z$ drugiej strony, podobnie jak na przykład Zofia Zarębianka (31-33, 15-28) - jako zapowiedź oryginalnej, „osobnej” już dykcji poetyckiej i myśli o sztuce Karola Wojtyły - Jana Pawła II. W myśli tej bowiem powraca idea „symfoniczności” wyartykułowana w młodzieńczym tomiku poezji. Ryzykując muzyczną metaforę, można powiedzieć, że powraca przetwarzana niczym główne tematy allegra sonatowego.

Zawsze lubiłem śpiewać - wyznaje Jan Paweł II w książce Wstańcie, chodźmy! - Mówiąc prawdę, śpiewałem właściwie przy każdej możliwej okazji. [...] Teksty bywały różne, zależnie od okoliczności: przy ognisku były to pieśni ludowe, harcerskie, a z racji świąt narodowych, rocznicy wybuchu wojny czy powstania warszawskiego śpiewało się teksty żołnierskie i patriotyczne. Spośród nich szczególnie lubię Czerwone maki na Monte Cassino, Pierwszą brygadę, w ogóle piosenki powstańcze i partyzanckie. (82)

W rodzimym kręgu kulturowym dobrze utrwalone są wspomnienia przedstawiające także Jana Pawła II śpiewającego z młodzieżą Barkę, swoją ulubioną „pieśń oazową", czy pastorałkę Oj Maluśki, Maluśki, do której Papież był szczególnie przywiązany. Proste, nawiązujące często do kantylenowej melodyki i tanecznych rytmów piosenki z kręgu kultury popularnej i ludowej, przeznaczone do śpiewania z towarzyszeniem zwykłej, akustycznej gitary, góralskich gęśli, fletów, najprostszych idiofonów. Niekiedy wizerunek Jana Pawła II nucącego podczas kolejnej wizyty w Polsce Barkę, przesłania nieco Jana Pawła II - subtelnego słuchacza i komentatora muzyki kościelnej (a także tej przeznaczonej do wykonywania w kościołach): chorału gregoriańskiego, kompozycji Hildegardy z Bingen, Palestriny, Haendla i Mozarta, Pendereckiego i Góreckiego, ale też - Moniuszki jako autora Strasznego dworu oraz Kilara z jego Krzesanym (zob. Ritter 379-386 i Karol Wojtyła - Jan Paweł II, Muzyka. Antologia tekstów 81-236).

Tym, co spaja te dwa wizerunki, jest przede wszystkim wyrażane przez Papieża przy różnych okazjach przekonanie o tym, że muzyka - ,język uniwersalny", „ekspresja Boga” - powinna pełnić przede wszystkim rolę mediacyjną: „łączyćc" (używając języka młodzieńczej poezji Wojtyły: „s c a la ć”). „Łączyć ludzi” (Karol

\footnotetext{
${ }^{3}$ Poezję Wojtyły czytam więc nieco inaczej niż Krzysztof Dybciak, który obecność tradycji romantycznej w tej twórczości widzi m.in. tak: „Niemniej mamy [...] do czynienia z paradoksem - niewątpliwy wpływ romantycznych idei na naszego poetę i dramaturga, a równolegle poetyka daleka od konwencji romantycznych: stłumiony emocjonalizm, brak wizyjności i fantastyki, opanowany subiektywizm, mało metafor i efektów muzycznych, ograniczona fabularność w dramatach...” („Wprowadzenie” 44).
} 
Wojtyła - Jan Paweł II, Muzyka. Antologia tekstów 273), ale też - „łączyć człowieka ze Stwórcą”, skłaniając do kontemplacji „odwiecznego piękna Boga”. O takim pojmowaniu sztuki dźwięków informują już same tytuły nadawane przemówieniom i homiliom kierowanym do muzyków przez Jana Pawła II - Arte musicale: un appello a meditare la bellezza [Sztuka muzyczna: wezwanie do medytacji nad pięknem; 1986], La musica avvicina gli uomini ai valori dello spirito [Muzyka łączy ludzi i uszlachetnia; 1986], L'arte della musica: espressione di Dio [Sztuka muzyczna ekspresją Boga; 1988], La musica, più delle altre arti, ci parla di cose sante e divie [Muzyka bardziej niż inne dziedziny sztuki mówi o sprawach świętych i Bożych; 1988], L'armonia della musica è invito a contemplare l'eterna bellezza di Dio [Harmonia muzyki jest zaproszeniem do kontemplacji odwiecznego piękna Boga; 1998] etc. (Ritter passim). Przywołajmy jeszcze kilka reprezentatywnych cytatów: „Muzyka posiada uniwersalny język [...]. Ludzkość potrzebuje piękna muzyki, która tłumaczy to, co duchowe, uwzniośla duszę, zwiększa wrażliwość i pomaga podnieść wzrok z radością. Możemy powiedzieć, że w pewien sposób, poprzez sztukę muzyczną człowiek staje się bardziej człowiekiem i chrześcijaninem" (Sztuka muzyczna: wezwanie do medytacji piękna, Di Filharmonica di Cannobio, Watykan 17 maja 1986; cyt. za: Muzyka. Antologia tekstów 169); „Muzyka ze swojej natury przybliża ludzi do wartości duchowych" (Muzyka łączy ludzi i uszlachetnia, audiencja dla Akademickiego Chóru im. Ivana Gorana Kovačićia z Zagrzebia, Watykan 17 stycznia 1987; cyt. za: Muzyka. Antologia tekstów 172); „[...] muzyka wprowadza nas w ducha modlitwy i jest wzniosłym wyrazem Bożego piękna" (Muzyka jest wyrazem Bożego piękna, Koncert w Auli Pawła VI, Watykan 3 grudnia 1988; cyt. za: Muzyka. Antologia tekstów 175); „Spośród przejawów ducha ludzkiego muzyka realizuje wzniosłe zadanie, jedyne i nie do zastąpienia. Kiedy jest prawdziwie piękna i pełna natchnienia, opowiada nam bardziej niż inne sztuki o Dobru, o wartości pokoju, o sprawach świętych i boskich" (Muzyka, bardziej niż inne dziedziny sztuki mówi o sprawach świętych i Bożych, do uczestników chóru Harmonici Cantores, Watykan, 23 grudnia 1988; cyt. za: Muzyka. Antologia tekstów 176); „Muzyka, będąca uniwersalnym językiem, już przez swą naturę może sprzyjać spotkaniu kultur [...]. Wznosi duszę ku szlachetnym i szczerym uczuciom, a poprzez harmonię dźwięków i dialog instrumentów może skłaniać do kontemplacji najwyższego i wiecznego Boskiego piękna" (Harmonia muzyki jest zaproszeniem do kontemplacji wiecznego piękna Boga, przemówienie na zakończenie koncertu zorganizowanego przez Akademia Musicae Pro Mundo Uno z Rzymu, Castel Gandolfo, 2 sierpnia 1988; cyt. za: Muzyka. Antologia tekstów 202).

Uprzywilejowanie muzyki jako tej, która „bardziej niż inne dziedziny sztuki mówi o sprawach świętych i Bożych”, jako mistycznej „mowy bez słów” pozwalającej na niewerbalną komunikację międzyludzką oraz na harmonijne połączenie 
wymiaru ludzkiego z Boskim, z łatwością można wywieść z ideologii romantycznej. Już w kręgu romantyków jenajskich, na przykład u Wackenrodera, znalazło wyraz przekonanie, że muzyka pozwala na najbliższy kontakt z Boskością, że ma charakter w swojej istocie religijny. „Żadna inna sztuka nie posługuje się jako surową materią czymś, co jest tak pełne niebiańskiego ducha” - pisze Wackenroder i dodaje: „[muzyka] odmalowuje człowiecze odczucia w sposób nadludzki [...] bowiem przemawia językiem, którego nie rozpoznajemy w życiu codziennym, którego pochodzenie i sposób, w jaki go opanowaliśmy, są nam nieznane, i który możemy jedynie nazwać językiem aniołów" (Das eigentümliche innere Wesen der Tonkust; cyt. za: Fubini 260). Wątki te zostały podjęte później na przykład przez Ernsta Theodora Amadeusza Hoffmanna, autora słynnej formuły mówiącej, że muzyka jest ,jedyną sztuką prawdziwie romantyczną, gdyż tylko nieskończoność stanowi jej przedmiot" (Beethovens Instrumental-Musik; cyt. za: Fubini 282), oraz Zygmunta Krasińskiego wyrażającego przekonanie, że „muzyka najwyższą jest mową ludzkości łączącą nas z zaświeciem duchów" (Krasiński 149-150). Z tego między innymi powodu romantyczni zwolennicy correspondance des arts postulowali syntezę sztuk realizowaną pod egidą muzyki: sztuki najwyższej.

Rzecz jasna, myśl romantyków na temat muzyki jest mocno zakorzeniona w refleksji starożytnych Greków i najstarszych Ojców Kościoła. Nawiązuje i do pitagorejskiej koncepcji „muzyki sfer”, i do Boecjuszowskiego De insitutione musica z popularnym w późniejszych epokach, zwłaszcza w średniowieczu, trójpodziałem (musica humana, musica mundana i musica instrumentalis; zob. m.in. Konik 51-74), i - może przede wszystkim - do tzw. pitagoreizmu neoplatońskiego, który, przejmując od pitagorejczyków przekonanie, że wszechświat opiera się na muzycznej harmonii, zastąpił Orfeusza biblijnym Dawidem, a muzykę utożsamił z samym „boskim Logosem”" W myśli jednego z najwybitniejszych reprezentantów estetyki „pitagoreizmu neoplatońskiego”, św. Augustyna, wyartykułowane jest przekonanie, że poznanie Boga może odbywać się za pośrednictwem sztuki muzycznej, i że to dopiero w służbie Bożej muzyka odnajduje swoją prawdziwą wartość i powołanie. Syntetycznie ujmuje to Leon Witkowski:

A zatem według św. Augustyna właściwym zadaniem muzyki jest wznosić człowieka od doczesności, od spraw zmysłowych i pospolitych, do wiecznej harmonii, która znajduje wyraz w muzyce. ... Harmonia ... jest dziełem i odzwierciedleniem Bóstwa. Objawia się w niej mądrość

\footnotetext{
${ }^{4}$ „Chodziło o właściwe zastąpienie pogańskiego ujęcia nauki - pisze Leon Witkowski - w tym przypadku nauki o muzyce, ujęciem nowym, chrześcijańskim. [...] Cel był zatem wyraźny: chodziło o przyswojenie współwyznawcom starożytnej pogańskiej nauki świeckiej, o jej uwznioślenie i nadanie jej kierunku etyczno-religijnego, aby skierowała ona ducha ku prawdzie, ku Bogu" (Św. Augustyna traktat „O muzyce” 17).
} 
Stwórcy. Osiągnięcie jej jest, według Augustyna, najwyższym prawem sztuki i zarazem najszlachetniejszym zadaniem chrześcijaństwa. (69)

Przekonanie to wyrażane jest i w przywołanych tu, dyskursywnych wypo-

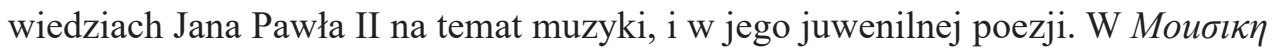
[Mousike] z cyklu Symphonie - Scalenia podmiot liryczny zwraca się do Boga:

Panie!

Ty jesteś Najwyższą Harmonią!

Twoja muzyka jest córą odwieczną -

i z wysokości Twoich sfer

zsyłasz melodii szczęście na ziemi.

(w. 54-58; Dzieła literackie 74)

To owa „Najwyższa Harmonia” rządzi - opiewaną przez młodego Wojtyłę harmonią Natury (,-- O Muzyko! Melodio! Muzyko!/ Ty wszechwładna! Harmonio natury!" - zwraca się na przykład podmiot liryczny emocjonalnie do muzyki, w. 21-22), którą można odczytywać tutaj zarówno w kontekście „muzyki Natury” (poeta przywołuje szum wiatru, odgłosy burzy, tajemniczą muzykę „Ziemi wnętrz” [w. 33] i głębi lasu [w. 14-16]), jak i Boecjuszowskiech relacji pomiędzy musica mundana i musica humana, gdzie człowiek próbuje okruchy idealnej harmonii sfer wyrazić w swojej własnej muzyce:

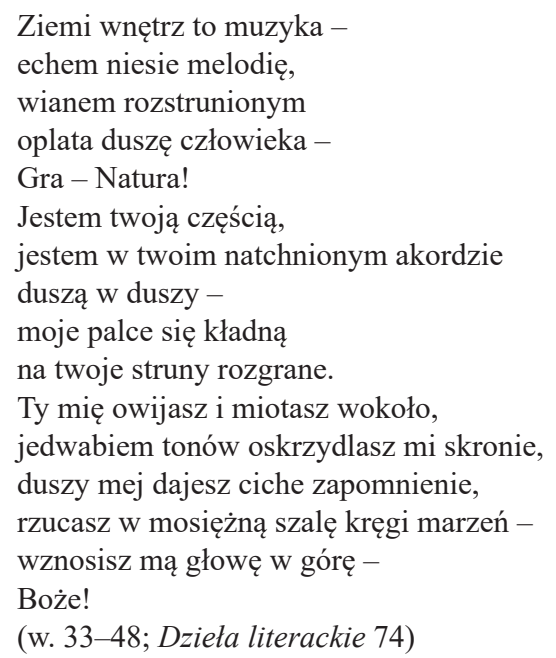

Jak to się jednak ma do „symfonii” i do idei „symfoniczności” zawartej w Psatterzu Dawidowym (Księdze Stowiańskiej)? 
Pojęcie „symfonia” w tekstach literaturoznawczych funkcjonuje najczęściej jako element stylistycznego ornatus, czyli w postaci zleksykalizowanej. Przeważnie bywa synonimem „różnorodności”, „bogactwa” - idei estetycznych i myślowych wpisanych w tekst, stylistyki, obrazowania literackiego, nawiązań intertekstualnych etc. Wystarczy przejrzeć na przykład cztery tomy monumentalnej monografii Juliusza Kleinera Juliusz Słowacki. Dzieje twórczości, by przekonać się, że mianem symfonii określa uczony bardzo różne teksty poety: zarówno młodzieńcze, jak i późne; te, które można uznać za wprawki literackie i te wybitne. Jako „symfonie” jawią się więc fragmenty Balladyny (pierwszy akt dramatu to "fantastyczno-groteskowa symfonia”, akt drugi „symfonia ludowo-baśniowa”, całość - „symfonia nastrojów”; Kleiner 2: 14, 19), passusy poematu W Szwajcarii, Poemów Piasta Dantyszka herbu Leliwa o Piekle, Jana Bieleckiego, Żmii, Beniowskiego, Księdza Marka, Samuela Zborowskiego, Genezis z Ducha i Króla-Ducha... (na ten temat: Seweryn 213-223). Podobną stylistykę można też spotkać przy okazji prac na temat twórczości innych romantyków, zwłaszcza Mickiewicza (zob. np. Kolbuszewski 189-196) i Norwida (Przesmycki 748-749). Bywa jednak i tak, że badacze wychodzą poza obszar muzycznej metaforyki i próbują doszukiwać się rzeczywistych analogii pomiędzy dziełem literackim a muzyczną formą symfonii (zob. np. Pociej 74; Wyka 63-65). Wkraczają zatem na poziom, który Steven Paul Scher określił mianem „muzyki w literaturze", wskazując na struktury i techniki muzyczne determinujące kształt formalny utworu literackiego, na prozodyczne i eufoniczne efekty tworzące „muzykę słów” oraz na motywy tematyczne składające się na „muzykę werbalną”. Jest to więc teren komparatystyki intersemiotycznej zajmującej się „muzycznością” literatury5.

Zauważmy jednak, że o ile obecność w dziele literackim motywów słownych z kręgu sztuki muzycznej czy kwestie związane z prozodią i eufonią wskazywane najczęściej jako elementy współtworzące ową „muzyczność” dzieła literackiego nie budzą na ogół większych zastrzeżeń (oczywiście pod warunkiem, że zrezygnujemy tu z szukania ścisłych odpowiedników pomiędzy obiema sztukami), to już próby

\footnotetext{
${ }^{5}$ Pozostałe poziomy interakcji literacko-muzycznych wyróżnione przez Schera to literatura w muzyce (muzyka programowa) oraz muzyka i literatura (muzyka wokalna) - zob. Scher 237. Klasyfikację Schera spopularyzował na gruncie polskim Andrzej Hejmej w swoich klasycznych już dla komparatystyki literacko-muzycznej pracach (zob. przede wszystkim: Muzyczność dzieła literackiego, passim). „Muzyczność” literatury to zagadnienie, które obrosło już pokaźną literaturą przedmiotu. Podstawowe dla tej problematyki rozprawy zbiera antologia Muzyka w literaturze. Antologia polskich studiów powojennych. Spośród najnowszych, porządkujących aktualny stan badań monografii wymieńmy przede wszystkim: Sułek 2016 (tu obszerny, fachowy Wstęp 11-43); Lisiecka 2016; Puchalska 2017 (tu szczególnie rozdział Literatura w perspektywie wiedzy o muzyce 17-49).
} 
szukania analogii strukturalnych pomiędzy gatunkiem literackim a muzyczną formą, napotykają na komplikacje powodowane odmiennością kodów strukturalnych, którymi posługują się muzyka i literatura. Czytając zatem, na przykład, Mała fugę z poematu Niobe Gałczyńskiego rozumiemy, że skojarzenie z muzyczną fugą nie odbywa się tutaj na zasadzie formalnej (precyzyjne, ścisłe oddanie muzycznych struktur polifonicznych za pomocą ,linearnie” prowadzonego tekstu literackiego jest bowiem praktycznie niemożliwe), lecz - na zasadzie tworzenia muzycznego kontekstu interpretacyjnego. Podobnie będzie na przykład z Mała symfonia , świecznikowa”, tego autora, a także z „symfoniami” innych poetów (np. Symfonia imion Lechonia, Niedokończona symfonią Hemara czy - choćby - Symfonia wielkomiejska Brzechwy).

Warto też pamiętać, że muzyczna metaforyka typu ,symfonia boru” czy „tajemna symfonia" była chętnie przywoływana i przez Kasprowicza (cytaty pochodzą z jego wierszy Przy szumie drzew i Marian Olchowicz), na którego powołał się Wojtyła w liście do Kotlarczyka, i przez poetów z kręgu „Czartaka” - Zegadłowicza i Szantrocha, którzy silnie oddziałali na autora Psałterza Dawidowego (Księgi Stowiańskiej) ${ }^{6}$. Wystarczy zacytować frazy z Sonetu XIII - choćby: „Wiatr w organ uderzy lasu, melodia poklęknie korna -” (w. 3); „Rozhymnij wietrzne organy!” (w. 7) - by uświadomić sobie, że metaforyka ta nie była też obca Wojtyle. Mając zaś na uwadze fakt, że już sam tytuł tomu ma charakter do pewnego stopnia metaforyczny (na „psałterz” składają się tu przecież nie psalmy - lecz sonety, symfonie i hymn; zatem „psałterz” Wojtyły jawi się nie jako „zbiór psalmów”, lecz rodzaj modlitewnika czy - może raczej - nacechowanej znaczeniowo idei'), można by założyć, że na podobnych zasadach funkcjonują interesujące nas ,symphonie - scalenia”. Zwłaszcza, że dwie z nich - Biesiada (-Poezja -) i Słowo - イogoৎ [Logos $]$ - mają podtytuły: ,poemat o sobie” oraz „rapsod”.

Upraszczając, powiedzmy, że muzyczna symfonia to cykliczna forma orkiestrowa, która opiera się na budowie cyklu sonatowego. Klasyczny model takiego cyklu tworzony jest przez cztery części (Allegro - Adagio - Menuet - Allegro). Zwłaszcza skrajne spośród nich komponowane są na schemacie allegra sonatowego, które z kolei rozpada się na ekspozycję, przetworzenie, repryzę oraz - niekiedy - codę. W ekspozycji mamy do czynienia z prezentacją dwóch, kontrastujących ze sobą tematów (przede wszystkim jest to kontrast tonalny, najczęściej także melodyczny i fakturalny). Przetworzenie - jak nazwa wskazuje - ma za zadanie przepracować

${ }^{6}$ Marta Burghardt zestawia Mousike z Krajobrazem muzycznym w Beskidzie Tadeusza Szantrocha, u którego pojawiają się na przykład „pól klawisze”, „organy chmur” grzmiące „groźnym chórem” etc. (224).

7 „Psałterz” jawi się tu jako „wartość” w rozumieniu takim, jakie zaproponował Marian Maciejewski w odniesieniu do miejsca eposu w myśli romantyków („Sławianie - synowie sławy” passim). 
materiał muzyczny obu tematów tak, by doprowadzić do zniwelowania kontrastu zarysowanego w ekspozycji. Prezentacja ,uzgodnionych” tematów ma miejsce w repryzie (zwanej też niekiedy rekapitulacją lub reekspozycją).

Żadna z „symphonii - scaleń” Wojtyły - choćby na zasadzie dalekiej analogii nie daje się wpisać w schemat muzycznej symfonii. Wydaje się jednak, że poematy

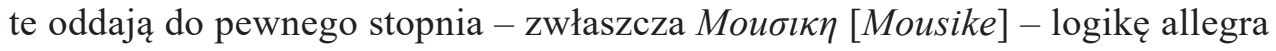
sonatowego.

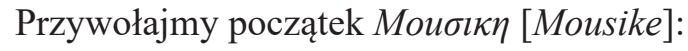

- Grajże, juhasie - na hali rozdzwoń się tonów kierdelem, głos twój się niesie po fali, potokiem rwie w dół wesele

- Idziesz, grajku, ulicą ponurą, płaczesz łzami - muzyką twej duszy, struny śpiewne jęczą ci do wtóru, domy biorą melodię - i głuszą

- Pienie wstrząsa gotyckiej katedry ściany, spływa na lud błogosławieństwem melodii W górę serca! Oczy rozmodlone w górę!

Otwórzcie w niebo na oścież muzyce bramy!

- - -

(w. 1-12; Dzieła literackie 71)

Dwie pierwsze strofy - bardzo wyraźnie oscylujące w stronę sylabotonizmu, co w poezji Karola Wojtyły - Jana Pawła II jest rzadkie, a wpisuje się w konwencje liryki „śpiewnej”8 - można potraktować jako ekspozycję: prezentację głównych tematów. Strofa pierwsza, pisana ośmiozgłoskowcem stylizowanym na metrum piosenki ludowej, byłaby odpowiednikiem tematu durowego („wesołego”). Druga - utrzymana w metrum dziesięciozgłoskowym i tylko w trzecim wersie gubiąca „rozkołysany”, regularny rytm trocheiczno-amfibrachiczny - mollowego (,,ponurego"). Strofa trzecia, toniczna - podążając takim tokiem rozumowania - byłaby odpowiednikiem muzycznego łącznika modulującego. Ów „łącznik modulujący” wprowadza motyw muzyki religijnej, pełniący podstawową rolę w połączeniu tematu idyllicznego (radosna muzyka wykonana przez juhasa) i melancholijnego (ponura muzyka ulicznego grajka). Nadaje ton przetworzeniu, w którym nadrzędne tematy

\footnotetext{
${ }^{8} \mathrm{O}$ tonizmie w poezji Wojtyły zob. wnikliwą rozprawę Witolda Sadowskiego „Czy Wojtyła pisał wiersze kotlarczykiem?” (415-429). „Śpiewność” rozumiem zgodnie z klasycznymi rozpoznaniami Czesława Zgorzelskiego w rozprawie „Elementy «muzyczności» w poezji lirycznej” (79-100).
} 
ulegają swoistej pracy „tematyczno-motywicznej”, by - uzgodnione („scalone”), w nowej tonacji powrócić w repryzie.

Zagrajcie miechy, trąby, organy,

w gotyckim chóry kościele!

- grać $\mathrm{z}$ wami będą na chwałę Panu

i chrząszcze, słowiki, i trzmiele.

Idź ty - śpiewaku - uliczny grajku od domu do domu!

i radość strunom lej w podarunku

i szafuj szczęściem tonów

Graj fujareczko na hali-

juhasie - raduj ucho!

O usłyszymy cię w dali:

Radości Pan Bóg słucha.

(w. 155-166; Dzieła literackie 78)

Przede wszystkim jednak rzecz nie w ścisłych analogiach formalnych, które zwłaszcza z perspektywy muzykologii bywają bardziej lub mniej dyskusyjne, lecz w pojmowaniu przez młodego poetę istoty symfonicznej formy sonatowej, opartej na dualizmie tematycznym i dążącej do jego przezwyciężenia. W Sonecie X z Psatterza Dawidowego (Księgi Stowiańskiej) zostało to zresztą wypowiedziane wprost: „I zgoda jest dziwna tej duszy słowiańskiej i Wawelu,/ jak jednych rąk melodia, jak symfoniczny prelud” (w. 13-14). „Symfoniczność” w ujęciu Wojtyły nie jest więc po prostu „różnorodnością”. Jest ,jednością w różnorodności”, uzgodnieniem, s c a le n i e m - jak to ujmuje poeta, który, rozumując w ten sposób, oddaje jednocześnie naturę muzycznego allegra sonatowego.

Na zbliżonych zasadach w pozostałych ,symphoniach - scaleniach” - Biesiadzie (-Poezji-) oraz Stowie - Logos [Logosie] przepracowane zostają, początkowo kontrastujące ze sobą, a potem „scalone”, wątki prezentujące źródła polskiej tradycji kulturowej (Prasłowiańszczyzna i chrześcijaństwo) oraz wyobrażenia na temat słowa wpisane w myśl starożytnej Grecji i w Biblię, zjednoczone w Słowie-Logosie.

Maciej Urbanowski, analizując Psatterz Dawidowy w kontekście poezji pokolenia wojennego, stwierdza, że „Wojtyła jest [...] profetą świata zharmonizowanego, świata »muzykalizacji«, jego rówieśnicy opisywali świat już (lub jeszcze) »zdemuzykalizowany «" (354). Z dystansem traktując określenie dziewiętnastoletniego poety „profetą", należy uznać za bardzo trafne zwrócenie uwagi na „muzykalizację”

\footnotetext{
${ }^{9}$ Bardziej trafne wydaje się stwierdzenie, że Karol Wojtyła intensywnie aktywizuje w Psałterzu Dawidowym konwencje właściwe dla romantycznej poezji profetycznej, wchodząc w rolę poety-
} 
świata w jego juwenilnych wierszach. „Muzykalizacja” ta - mająca swoje głębokie korzenie w myśli romantyków i w romantycznej correspondance des arts - w poezji Autora Psałterza Dawidowego nierozerwalnie łączy się z ideą specyficznie pojętej „symfoniczności”, która w późniejszej refleksji Jana Pawła II wyrazi się i utrwali w przekonaniu o mediacyjnej roli muzyki. O jej roli scalającej.

\section{BIBLIOGRAFIA}

Burghardt, Marta. Wadowickie korzenie Karola Wojtyły. Wadowickie Centrum Kultury im. Macieja Wadowity, 2013.

Chrząstowska, Bożena. „„Pieśni - przeczucia« - młodzieńcze poezje Karola Wojtyły”. Polonistyka, nr 9, 2009, ss. 30-35.

Dybciak, Krzysztof. Karol Wojtyta a literatura. Wydawnictwo Diecezji Tarnowskiej Biblos, 1991.

Dybciak, Krzysztof. „Wprowadzenie”. Pisarstwo Karola Wojtyły - Jana Pawła II w oczach krytyków i uczonych. Antologia, oprac. Krzysztof Dybciak, Państwowy Instytut Wydawniczy, 2019, ss. 10-48.

Dziedzic, Stanisław. „Pieśń nieprzebrzmiała. Juwenilia Karola Wojtyły”. Pisarstwo Karola Wojtyły Jana Pawła II w oczach krytyków i uczonych. Antologia, oprac. Krzysztof Dybciak, Państwowy Instytut Wydawniczy, 2019, ss. 470-504.

Dziedzic, Stanisław. „«Pieśń polskim i słowiańskim duchem przepojona». O juveniliach literackich Karola Wojtyły”. Roczniki Humanistyczne, z. 7: Stowianoznawstwo, t. 45/46, 1997-1998, ss. 149-160.

Fubini, Enrico. Historia estetyki muzycznej. Tłum. Zbigniew Skowron, Musica Iagiellonica, 1997.

Hejmej, Andrzej. Muzyczność dzieła literackiego. Wydawnictwo Funna, 2001.

Jan Paweł II. Wstańcie, chodźmy! Wydawnictwo św. Stanisława BM, 2004.

Karol Wojtyła - poeta, red. Jacek Głażewski i Witold Sadowski, Wydawnictwa Uniwersytetu Warszawskiego, 2006.

Karol Wojtyła / Jan Pawet II wobec tradycji kultury polskiej, red. Grażyna Halkiewicz-Sojak i in. Wydawnictwo Naukowe Uniwersytetu Mikołaja Kopernika, 2015.

Kleiner, Juliusz. Juliusz Stowacki. Dzieje twórczości, t. II: Od „Balladyny” do „Lilli Wenedy”. Wstęp i oprac. Jerzy Starnawski, Wydawnictwo Literackie, 1999.

Kolbuszewski, Stanisław. „Muzyczność Pana Tadeusza”. Stanisław Kolbuszewski. Romantyzm i modernizm: studia o literaturze i kulturze. Wydawnictwo „Sląsk”, 1959, ss. 189-196.

Konik, Marcin. „Muzyka u Boecjusza i w filozofii średniowiecznej”. Archiwum Historii Filozofii i Myśli Społecznej, t. 50-51, 2006, ss. 51-74.

Kozłowska, Anna. Od psalmów słowiańskich do rzymskich medytacji. O stylu artystycznym Karola Wojtyly. Wydawnictwo Uniwersytetu Kardynała Stefana Wyszyńskiego, 2013.

Kozłowska, Anna. „Wobec tradycji literackiej: poezja z ducha Norwida”. Pisarstwo Karola Wojtyly - Jana Pawła II w oczach krytyków i uczonych. Antologia, oprac. Krzysztof Dybciak, PIW, 2019, ss. 524-548.

Krasiński, Zygmunt. „List do Konstantego Gaszyńskiego z 9 stycznia 1837”. Zygmunt Krasiński. Listy do Konstantego Gaszyńskiego, oprac. Zbigniew Sudolski, Państwowy Instytut Wydawniczy, 1971, ss. 149-150.

-wieszcza. Słuszność mają badaczki, które wskazują na silne zakorzenienie obrazowania i stylistyki poetyckiej młodego Wojtyły w twórczości późnego Słowackiego (zob. Przybylska, „Źródła mistyki «Poezji i dramatów»”; Kozłowska, „Wobec tradycji literackiej: poezja z ducha Norwida”). 
Lisiecka, Małgorzata. Staropolska melopoesis. Stowo i muzyka w poezji polskiej 1600-1750 wobec refleksji teoretycznej. Wydawnictwo Naukowe Uniwersytetu Mikołaja Kopernika, 2016.

Maciejewski, Jarosław. „Karol Wojtyła i Jan Paweł II wobec literatury”. Pisarstwo Karola Wojtyly Jana Pawła II w oczach krytyków i uczonych. Antologia, oprac. Krzysztof Dybciak, Państwowy Instytut Wydawniczy, 2019, ss. 168-218.

Maciejewski, Marian. „Sławianie - synowie sławy (epos jako wartość)”. Marian Maciejewski Poetyka-Gatunek-Obraz. W kręgu poezji romantycznej. Zakład Narodowy im. Ossolińskich, 1977, ss. 11-25.

Muzyka w literaturze. Antologia polskich studiów powojennych, oprac. Andrzej Hejmej, Universitas, 2002.

Pociej, Bohdan. „Muzyczność Uspokojenia”. Potracić strunę poezji kamienną. Szkice o „Uspokojeniu” Juliusza Stowackiego, red. Stanisław Makowski, Państwowy Instytut Wydawniczy, 1979, ss. 70-82.

Popiel, Jacek. „Wprowadzenie”. Karol Wojtyła - Jan Paweł II. Dzieła literackie i teatralne, t. I: Juwenilia (1938-1946), red. Jacek Popiel i in., Znak, 2019.

Przesmycki, Zenon. „Komentarze”. Cyprian Norwid. Pisma zebrane, t. A cz. 2, wyd. Zenon Przesmycki, Wydawnictwo Jakuba Mortkowicza, 1912, ss. 748-749.

Przestrzeń słowa. Twórczość literacka Karola Wojtyly - Jana Pawła II, red. Zofia Zarębianka i Jan Machniak, Wydawnictwo św. Stanisława BM, 2006.

Przybylska, Agata. „O Renesansowym psałterzu Karola Wojtyły”. Ruch Literacki, nr 3, 2000, ss. 355-365.

Przybylska, Agata. Samotność możliwa w człowieku. Mistyczny aspekt „Poezji i dramatów” Karola Wojtyly. Arcana, 2002.

Przybylska, Agata. „Źródła mistyki Poezji i dramatów”. Pisarstwo Karola Wojtyły - Jana Pawła II w oczach krytyków i uczonych. Antologia, oprac. Krzysztof Dybciak, PIW, 2019.

Puchalska, Iwona. Muzyka w okolicznościach lirycznych. Zapisy stuchania muzyki w poezji polskiej XX i XXI wieku. Księgarnia Akademicka, 2017.

Ritter, Cezary. „Muzyka - piękno, dobro, świętość. Bibliografia wypowiedzi Jana Pawła II z lat 19782005". Ethos, nr 1-2 (73-74), 2006, ss. 379-386.

Sadowski, Witold. „Czy Wojtyła pisał wiersze kotlarczykiem”. Pisarstwo Karola Wojtyty - Jana Pawła II w oczach krytyków i uczonych. Antologia, oprac. Krzysztof Dybciak, Państwowy Instytut Wydawniczy, 2019, ss. 441-457.

Scher, Steven Paul. „Literature and Music”. Interrelations of Literature, ed. Jean-Pierre Barricelli, and Joseph Gibaldi, Modern Language Association of America, 1982, pp. 225-250.

Seul, Anastazja. Literatura polska w wypowiedziach Jana Pawła II. Sacrum, Prawda, Dobro, Piękno. Wydawnictwo Rys, 2014.

Seweryn, Agata. „«Najsubtelniejszy muzyk w poezji»? Juliusz Słowacki a muzyka”. Roczniki Humanistyczne, t. 55, z. 1, 2006, ss. 149-235.

Sułek, Małgorzata. Stanisław Moniuszko i inni kompozytorzy wobec poezji Adama Mickiewicza. Studium komparatystyczne. Musica Iagiellonica, 2016.

Szymański, Wiesław Paweł. Z mroku korzeni. O poezji Karola Wojtyty. Calvarianum, 1989.

Św. Augustyna traktat „O muzyce”. Tłum. Leon Witkowski, red. Remigiusz Popowski, Redakcja Wydawnictw Katolickiego Uniwersytetu Lubelskiego, 1999.

Wojtyła, Karol - Jan Paweł II. Dzieła literackie i teatralne, t. 1: Juwenilia (1938-1946), red. Jacek Popiel i in., Znak, 2019.

Wojtyła, Karol - Jan Paweł II. Muzyka. Antologia tekstów, red. Dariusz Radziechowski. Wyd. 2, Akademia Muzyczna w Krakowie, 2015.

Wyka, Kazimierz. Cyprian Norwid. Poeta i sztukmistrz. Polska Akademia Umiejętności, 1948.

Zarębianka, Zofia. Spotkanie w Stowie. O twórczości literackiej Karola Wojtyły. Wydawnictwo Pasaże, 2018.

Zgorzelski, Czesław. „Elementy «muzyczności» w poezji lirycznej”. Muzyka w literaturze. Antologia studiów powojennych, red. Andrzej Hejmej, Universitas, 2002, ss. 79-100. 


\section{POETYCKIE SYMFONIE KAROLA WOJTYŁY}

\section{Streszczenie}

Tematem artykułu jest cykl Symphonie - Scalenia zawarty w juwenilnym tomie poezji Karola Wojtyły zatytułowanym Psałterz Dawidów (Księga Słowiańska). Autorka, koncentrując się na semantyce terminu „symfonia” użytego przez młodego poetę w kontekście genologicznym, wskazuje na tradycje literackie, z których można wywieść koncepcję łączenia gatunków literackich i muzycznych, zwłaszcza

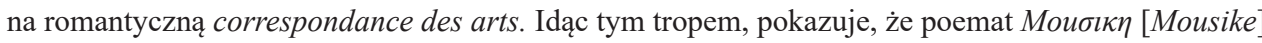
można czytać jako literacki odpowiednik allegra sonatowego. Przede wszystkim interesuje ją jednak sama idea „symfoniczności” w ujęciu Wojtyły, która ewoluowała w późniejszej myśli o muzyce Jana Pawła II. W uprzywilejowaniu przez Papieża sztuki dźwięków jako mistycznej „,mowy bez słów” pozwalającej na harmonijne połączenie wymiaru ludzkiego z Boskim, autorka dostrzega przetworzenie młodzieńczej idei „symfoniczności” pojmowanej w kategoriach mediacyjnych (jako „scalanie”, „uzgadnianie”, „łączenie”).

Słowa kluczowe: Karol Wojtyła; juwenilia; muzyka i literatura; korespondencja sztuk; tradycja romantyczna.

\section{THE POETIC SYMPHONIES OF KAROL WOJTYŁA}

\section{Sum mary}

The subject of this article is the Symphonie - Scalenia [Symphonies - Unifications] series contained in the juvenilia volume of Karol Wojtyła's poetry entitled Psatterz Dawidów (Księga Stowianska) [The Psalter of David (The Slavonic Book)]. The author, focusing on the semantics of the term "symphony," points to those literary traditions from which the concept of combining literary and musical genres can be derived, especially the romantic correspondance des arts. Following this lead, the article shows that the poem Mоuбıкп [Music] can be understood as the literary equivalent of a sonata-allegro. Above all, however, the author is interested in the very idea of the "symphony" in Wojtyła's approach, which evolved in the later writings of John Paul II on music. The Pope's favouring of the art of sounds as a mystical "speech without words," which enables the harmonious combination of the human and the divine, is here presented as the transformation of his youthful idea of a "symphony" as comprehended in mediatorial terms ("merging," "reconciliation," "connecting").

Keywords: Karol Wojtyła; juvenilia; music and literature; correspondance des arts; romantic tradition 